\title{
CAML regulates Bim-dependent thymocyte death
}

\author{
CE Edgar $^{1}$, LD Lindquist ${ }^{2}$, DL McKean ${ }^{1}$, A Strasser ${ }^{3}$ and RJ Bram ${ }^{\star, 1,2,3}$
}

Appropriate control of apoptosis during $T$ lymphocyte differentiation is critical for destruction of $T$ cells bearing potentially autoreactive or useless immuno-receptors and for survival of those $T$ cells bearing antigen receptors that may recognize foreign proteins. Despite the well-established importance of thymocyte survival, the exact signals regulating thymocyte apoptosis have not been fully elucidated. Here, we show that thymocytes lacking the endoplasmic reticulum protein calcium-modulating cyclophilin ligand (CAML) failed to undergo normal T-cell development and exhibited dramatically increased rates of apoptosis. In vitro, CAML-deficient thymocytes accumulated high levels of reactive oxygen species (ROS) and underwent abnormally accelerated death in response to several cytotoxic stimuli, including treatment with etoposide, cytokine deprivation, or Fas ligation. Although neither p53 deletion nor loss of Fas rescued the survival and continued development of CAML-deficient thymocytes, removal of the pro-apoptotic BH3-only Bcl-2 family member Bim significantly restored their survival. This work reveals CAML to be a critically important regulator of ROS- and Bim-dependent thymocyte death.

Cell Death and Differentiation (2010) 17, 1566-1576; doi:10.1038/cdd.2010.30; published online 19 March 2010

Cell survival during T-cell development is a carefully controlled process. Early in development, signals through the pre-T-cell receptor (pre-TCR, composed of TCR $\beta$ and $\mathrm{pT} \alpha$ ) promote proliferation, survival, and differentiation of immature (CD4-CD8-) progenitors. Further rearrangement of the $\alpha$ chain of the TCR completes the assembly of the T-cell antigen receptor, and thymocytes are then subjected to stringent selection based on its specificity. Cells bearing a TCR with low affinity for self-peptide bound to a self-MHC molecule receive a survival signal and undergo continued differentiation, a process termed as positive selection. Thymocytes with receptors that have high affinity for selfpeptide MHC complexes undergo apoptosis in a process called negative selection, whereas those cells that are unable to bind any ligand undergo death by neglect. ${ }^{1}$ The developing thymocyte has a window of opportunity during which to sample a variety of ligand/MHC complexes and receive a positively selecting signal before it undergoes programed cell death, but the signals maintaining thymocyte viability and the pathways that control cell survival or death in response to these interactions are not well understood.

Mammalian cells, including thymocytes, have two distinct, albeit ultimately converging, pathways of apoptosis: the 'extrinsic' ('death receptor'-controlled) pathway and the 'intrinsic' (also called 'mitochondrial' or 'Bcl-2-regulated') pathway. ${ }^{2}$ The 'extrinsic' pathway is activated by certain members of the TNF family of ligands that bind to the so-called 'death receptors' (members of the TNF receptor family with an intracellular 'death domain') on the cell surface, triggering a cascade of intracellular events that result in cell death. ${ }^{2}$ Conversely, the 'intrinsic' apoptotic pathway is regulated by the balance between pro- and anti-apoptotic members of the Bcl-2 family. The pro-survival Bcl-2 family members - Bcl-2, $\mathrm{Bcl}-\mathrm{x}_{\mathrm{L}}, \mathrm{Bcl}-\mathrm{w}, \mathrm{Mcl}-1$, and $\mathrm{A} 1$ - share with each other up to four regions of homology (BH, Bcl-2 homology regions) and are essential for cell survival functioning in a cell type-specific manner. There are two pro-apoptotic subgroups within the $\mathrm{Bcl}-2$ family. Bak, Bax, and possibly also Bok have three $\mathrm{BH}$ domains and share surprising structural similarity with their pro-survival relatives, but are essential (in a redundant manner) for downstream events in apoptosis, including mitochondrial outer membrane permeabilization (MOMP) and consequent activation of the caspase cascade. $\mathrm{BH} 3-$ only proteins, on the other hand, share with each other and the remainder of the $\mathrm{Bcl}-2$ family only the $\mathrm{BH} 3$ domain and they are critical for initiation of apoptosis signaling, functioning in a cell death stimulus- and cell type-specific manner. ${ }^{2}$

$\mathrm{Bcl}-2$-interacting mediator of cell death (Bim) is a BH3-only $\mathrm{Bcl}-2$ family member that is transcriptionally and/or posttranslationally induced in response to diverse apoptotic stimuli, such as cytokine deprivation or deregulated calcium flux, in a broad range of hematopoeitic, epithelial, and neuronal cell types. ${ }^{3-5}$ Experiments with gene-targeted mice showed that Bim is required for the death of thymocytes in response to growth factor withdrawal, calcium flux, taxol treatment, as well as strong T-cell receptor ligation. ${ }^{6,7} \mathrm{Bim}$ is also critical for the apoptosis of peripheral $T$ cells during the contraction phase of an acute immune response. ${ }^{8-10}$ As a potent mediator of cell death, Bim is highly regulated both transcriptionally and post-translationally. Bim is found in three major isoforms that have differing levels of pro-apoptotic activity ${ }^{4}$ and are each regulated by various post-translational

\footnotetext{
${ }^{1}$ Department of Immunology, Mayo Clinic College of Medicine, Rochester, MN, USA; ${ }^{2}$ Department of Pediatrics and Adolescent Medicine, Mayo Clinic College of Medicine, Rochester, MN, USA and ${ }^{3}$ Department of Molecular Genetics of Cancer, The Walter and Eliza Hall Institute of Medical Research, Parkville, Victoria, Australia ${ }^{*}$ Corresponding author: RJ Bram, Department of Pediatrics and Adolescent Medicine, The Mayo Clinic College of Medicine, 200 First Street SW, Rochester, MN 55905, USA. Tel: 507266 0378; Fax: 507284 3757; E-mail: bram.richard@mayo.edu

Keywords: T-cell development; CAML; ROS; Bim

Abbreviations: CAML, calcium-modulating cyclophilin ligand; ROS, reactive oxygen species; Bim, Bcl-2-interacting mediator of cell death; MOMP, mitochondrial outer membrane permeabilization

Received 29.10.09; revised 17.2.10; accepted 17.2.10; Edited by S Kumar; published online 19.3.10
} 
mechanisms, including phosphorylation, ${ }^{11}$ proteosomal degradation, ${ }^{12}$ and sequestration to the microtubular dynein motor complex. ${ }^{13}$ Although much is known about Bim regulation, questions still remain as to which signaling pathways directly inhibit or promote Bim activity.

Calcium-modulating cyclophilin ligand (CAML) is a transmembrane protein that localizes to the endoplasmic reticulum and small cytoplasmic vesicles. ${ }^{14,15}$ It is ubiquitously expressed and evolutionarily highly conserved in all vertebrates. The exact cellular function of CAML is still unknown, but it has been implicated in diverse cell signaling processes, including calcium signaling, ${ }^{14}$ protein trafficking, ${ }^{16}$ and chromosome segregation. ${ }^{17}$ A CAML conditional knockout mouse in which CAML was deleted relatively late during thymic T-cell development has been described. ${ }^{18}$ In that study, using $\mathrm{CAML}^{\mathrm{fl} / \mathrm{fl}}$ mice expressing the jmlckcre transgene, it was observed that CAML-deficient cells experienced increased T-cell receptor stimulation, but that the overall processes of positive and negative selection were intact. ${ }^{19}$ Although earlier work suggested that CAML-deficient cells were more susceptible to apoptosis in response to T-cell receptor stimulation compared with control cells, there was no direct evidence that CAML-deficient CD4 + CD8 + (double positive, DP) thymocytes exhibit abnormally high rates of apoptosis. Furthermore, it was not examined how CAML may interact with apoptotic signaling pathways.

This study represents the first description of mice in which CAML is deleted during the double negative 2 (DN2)/DN3 stage of development, considerably earlier than the timing of excision reported for the cam $f^{f / f l}$ mice expressing the jmlckcre transgene. In our study, we observed severe reductions in thymocyte subsets, beginning at the DN4 stage of development, which was due to increased apoptosis and did not result from a defect in cell proliferation. The loss of cellularity was dependent on the presence of Bim, but did not require T-cell receptor ligands (peptide/MHC complexes), p53, or Fas signaling.

\section{Results}

Loss of CAML early in T-cell development leads to a severe reduction in thymocyte numbers because of abnormally increased apoptosis. To determine the function of CAML in early T-cell development, we crossed mice bearing loxP-flanked $\mathrm{Caml}$ alleles $\left(\mathrm{CAML}^{\mathrm{fl} / \mathrm{fl}}\right)$ to $\mathrm{cwLckCre}$ mice, which express the Cre recombinase before the DN3 stage of thymocyte development. ${ }^{20}$ The cwLckCre-CAML ${ }^{\mathrm{fl} / \mathrm{fl}}$ mice showed a severe depletion of total thymocytes (Figure 1a) in comparison with littermate control $\mathrm{CAML}^{\mathrm{fl} / \mathrm{fl}}$ mice. To investigate whether early T-cell development was impaired by CAML deletion, we examined lineage marker (Mac-1, GR-1, CD8 $\alpha, \operatorname{TCR} \beta, \operatorname{TCR} \gamma \delta, \mathrm{CD} 3 \varepsilon, \mathrm{B} 220, \mathrm{CD} 19$, Ter119, and NK1.1)-negative thymocytes for expression of c-kit and CD25 (Figure 1b). Quantitation of the earliest subsets of T cells: ETPs (lin-, c-kit +, and CD25-), DN2 (lin-, c-kit + , and CD25 + ), and DN3 (lin-, c-kit-, and CD25+) indicated that the numbers of these cells were similar between cwLckCre-CAML ${ }^{\mathrm{fl} / \mathrm{fl}}$ and control $\mathrm{CAML}^{\mathrm{fl} / \mathrm{fl}}$ mice. However, the numbers of DN4 cells (lin-, c-kit-, CD25-) were reduced by $\sim 50 \%$ in cwLckCre-CAML ${ }^{\mathrm{fl} / \mathrm{fl}}$ compared with $\mathrm{CAML}^{\mathrm{fl} / \mathrm{fl}}$ mice (Figure 1c). By staining thymocytes for expression of CD4 and CD8, we found that loss of CAML caused an $80-90 \%$ reduction in the percentages and total numbers of DP (CD4+CD8+, DP), CD4 single-positive (CD4+CD8-, SP), as well as CD8 SP (CD4-CD8+) subsets compared with littermate controls (Figure 1d-e).

In comparison with jmlckcre-CAML ${ }^{\mathrm{fl} / \mathrm{fl}}$ mice $^{19}$ the $\mathrm{cwLckCre} \mathrm{CAML} \mathrm{fl}^{\mathrm{fl} l}$ mice contained strikingly fewer thymocytes overall and within all subsets from the DN4 to the SP stages of development. For example, CD4 + CD8 + DP cells in jmlckcre-CAML ${ }^{\mathrm{fl} / \mathrm{fl}}$ thymi were reduced 2.2-fold compared with age-matched littermate $\mathrm{CAML}^{\mathrm{fl} / \mathrm{fl}}$ controls, whereas in cwLckCre-CAML ${ }^{\mathrm{fl} / \mathrm{fl}} \mathrm{CD} 4+\mathrm{CD} 8+\mathrm{DP}$, cells were reduced 8.6-fold compared with $\mathrm{CAML}^{\mathrm{fl} / \mathrm{fl}}$ age-matched littermate controls. In the single-positive populations, jmlckcre-CAML ${ }^{\text {fl/fl }}$ thymi had 7.9-fold fewer CD4 + CD8 - SP cells compared with control littermates, whereas the cwLckCre-CAML ${ }^{\mathrm{fl} / \mathrm{fl}} \mathrm{CD} 4+$ CD8- SP cells had 19.4-fold fewer cells compared with $\mathrm{CAML}^{\mathrm{fl} / \mathrm{fl}}$ thymi. Finally, in the CD4-CD8 + SP population, jmlckcre-CAML ${ }^{\mathrm{fl} / \mathrm{fl}}$ thymi had 5.2-fold fewer cells when compared with $\mathrm{CAML}^{\mathrm{fl} / \mathrm{fl}}$ age-matched littermate controls, whereas cwLckCre-CAML ${ }^{\mathrm{fl} / \mathrm{fl}} \mathrm{CD} 4-\mathrm{CD} 8+\mathrm{SP}$ cells had 7.3-fold fewer cells compared with $\mathrm{CAML}^{\mathrm{fl} / \mathrm{fl}}$ age-matched littermate controls.

To ensure the efficiency of deletion of the floxed Caml alleles in $\mathrm{cwLckCre}^{-C A M L} \mathrm{~L}^{\mathrm{fl} / \mathrm{fl}}$ cells, we used magnetic sorting to enrich for CD4-CD8-CD44-CD25- (DN4) or CD4+ CD8 + cells. Western blotting revealed that cwLckCre$\mathrm{CAML}^{\mathrm{fl} / \mathrm{fl}}$ cells had a $>90 \%$ reduction in CAML expression compared with CAML ${ }^{\mathrm{fl} / \mathrm{fl}}$ control cells (Figure 1f).

We next examined whether the loss of thymocytes in cwLckCre-CAML ${ }^{\mathrm{fl} / \mathrm{fl}}$ mice was due to increased cell death or decreased proliferation. We examined the number of apoptotic cells by staining with Annexin $\mathrm{V}$ and propidium iodide. A larger percentage of cells in each major thymocyte subset stained positive for Annexin $\mathrm{V}$ and propidium iodide in cwLckCre$\mathrm{CAML}^{\mathrm{fl} / \mathrm{fl}}$ cells compared with $\mathrm{CAML}^{\mathrm{fl} / \mathrm{fl}}$ littermates (Figure 2a).

As CAML has been implicated as a regulator of the mitotic spindle checkpoint, and CAML-deficient cells were reported to exhibit defects in cellular division, ${ }^{17}$ it was important to determine whether CAML is essential for mitosis in thymocytes. To determine whether CAML loss was accompanied by defective proliferation, we injected mice with 2-bromodeoxyuridine (BrdU) and then removed thymi after $90 \mathrm{~min}$. Thymocytes were surface stained with antibodies to CD4 and CD8 to define the four major thymocyte subsets and intracellularly with an antibody to BrdU to measure the rate of incorporation of this thymidine analog into dividing cells. Cells of all thymocyte subsets from cwLckCre-CAML ${ }^{\text {fl/fl }}$ showed increased proliferation compared with control $\mathrm{CAML}^{\mathrm{fl} / \mathrm{fl}}$ littermates (Figure $2 b$ ). Thus, we conclude that loss of CAML early in T-cell development decreases the ability of pre-T cells to survive, resulting in reduced thymic numbers beginning at the DN4 stage of development (and possibly a compensatory increase in cell cycling). In addition, the increase in proliferation in DN and DP subsets indicates that cwLckCre-CAML ${ }^{\mathrm{fl} / \mathrm{fl}}$ cells have intact pre-TCR signaling and that lack of a signal through the pre-TCR cannot account for the loss of the DP cwLckCre-CAML ${ }^{\text {fl/fl }}$ cells. 

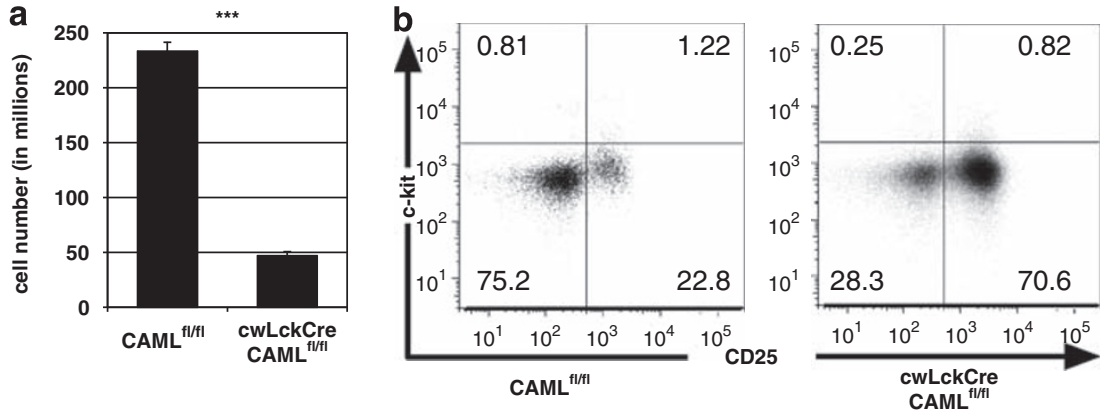

d
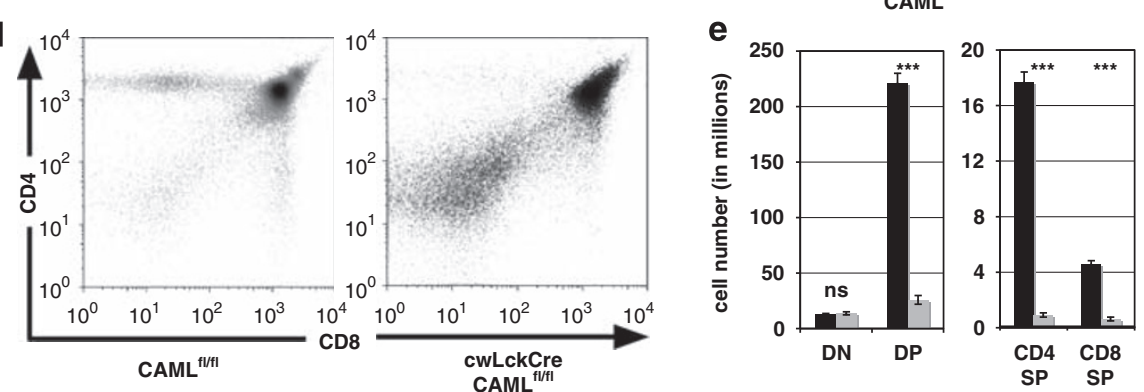
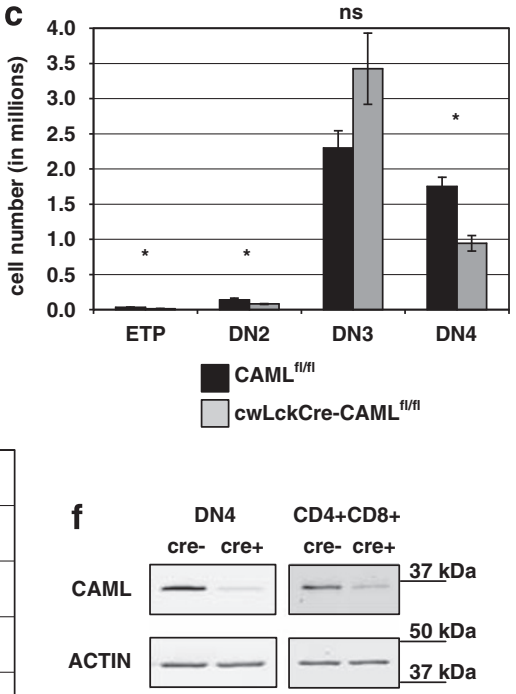

Figure $1 \mathrm{cwLckCre-CAML}{ }^{\text {fl/til }}$ mice exhibit a defect in thymocyte development, beginning at the DN4 stage. (a) Thymocytes from 3- to 6-week-old cwLckCre-CAML ${ }^{\text {fl/ft }}$ mice or littermate controls were tweezed into single cell suspensions and counted; $n=50+$ for each genotype. (b) Cells were stained for surface expression of lineage markers, CD44, and CD25. Lineage marker (Mac-1 (CD11b), GR-1 (Ly6G/C), CD8 $\alpha$, TCR $\beta$, TCR $\gamma \delta$, CD3 $\varepsilon$, B220, CD19, Ter119, and NK1.1)-negative cells were analyzed for c-kit and CD25 expression, as shown in the representative flow cytometry profiles. (c) Lineage-negative subsets were quantified. ETP (lin-, c-kit +, and CD25-), DN2 (lin-, c-kit + , and CD25 + ), DN3 (lin-, c-kit-, and CD25 + ), and DN4 (lin-, c-kit-, and CD25-); $n=5$ for each genotype. (d) Total thymocytes were analyzed for expression of CD4 and $\mathrm{CD} 8$, as shown in these representative flow cytometry profiles. (e) $C D 4$ and $C D 8$ subsets were quantified; $n=17$ for each genotype. Error bars represent standard error of the mean. (f) Total thymocytes were sorted using Miltenyi MACS beads based on expression of CD4, CD8, CD44, and CD25. CD4-CD8-CD44-CD25- (DN4) and $\mathrm{CD} 4+\mathrm{CD} 8+$ cells were isolated and lysed with $1 \%$ Triton lysis buffer. Western blots were probed for CAML and actin (loading control) levels. ${ }^{*} P<0.05,{ }^{* \star \star} P<0.001$
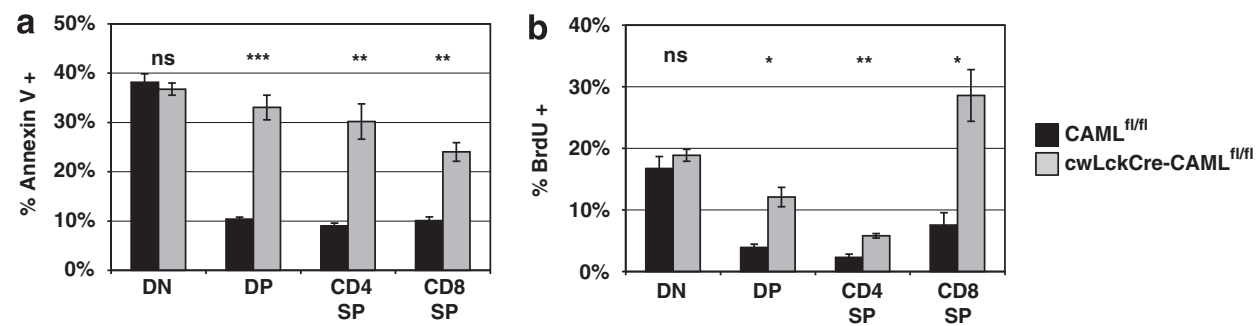

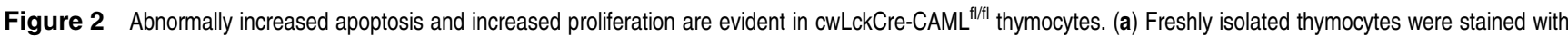
anti-CD4 plus anti-CD8 antibodies plus Annexin V-Cy5 and propidium iodide to determine the percentage of apoptotic cells in each of the four major thymocyte subsets. Data from one representative of three independent experiments is shown; $n=5$ of each genotype. (b) Mice were injected intraperitoneally with $15 \mu \mathrm{g}$ BrdU. After 90 min, thymocytes were isolated and stained for surface expression of CD4 and CD8 and intracellularly for uptake of BrdU; $n=3$ of each genotype. Error bars represent standard error of the mean. ${ }^{*} P<0.05,{ }^{* \star} P<0.005,{ }^{* \star *} P<0.001$

CAML is critical for thymocyte survival after exposure to a specific subset of apoptotic stimuli. To further investigate the differences in survival between control and CAMLdeficient thymocytes, we subjected cwLckCre-CAML ${ }^{\mathrm{fl} / \mathrm{fl}}$ and control CAML ${ }^{\text {fl/fl }}$ cells to a variety of apoptotic stimuli. We observed that in response to treatment with phorbol ester, ionomycin, thapsigargin, staurosporine, dexamethasone, or hydrogen peroxide, cell death was comparable between control and CAML-deficient cells (Figure 3 ). In contrast, cwLckCre$\mathrm{CAML}^{\mathrm{fl} / \mathrm{fl}}$ thymocytes were significantly more sensitive than control cells to certain other stimuli, including cytokine deprivation, treatment with etoposide (even 100-fold lower concentrations), or stimulation of the death receptor Fas (Figure 3).
P53 is not required for the enhanced apoptosis caused by CAML deficiency. Cell death after treatment with the topo-II inhibitor etoposide is dependent on p53 and its transcriptional induction of the pro-apoptotic $\mathrm{BH} 3-$ only protein Puma. ${ }^{21}$ To investigate whether the enhanced apoptosis in CAML-deficient thymocytes might be due to abnormally increased activation of p53, we crossed cwLckCre-CAML $L^{\mathrm{fl} / \mathrm{fl}}$ mice to $\mathrm{p} 53^{-/-}$animals. However,

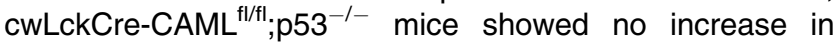
thymocyte numbers compared with $\mathrm{cwLckCre}^{-C A M \mathrm{~L}^{\mathrm{fl} / \mathrm{fl}}}$ controls (Supplementary Figure S1), indicating that p53 is not required for CAML-deficiency-induced thymocyte death in vivo. 

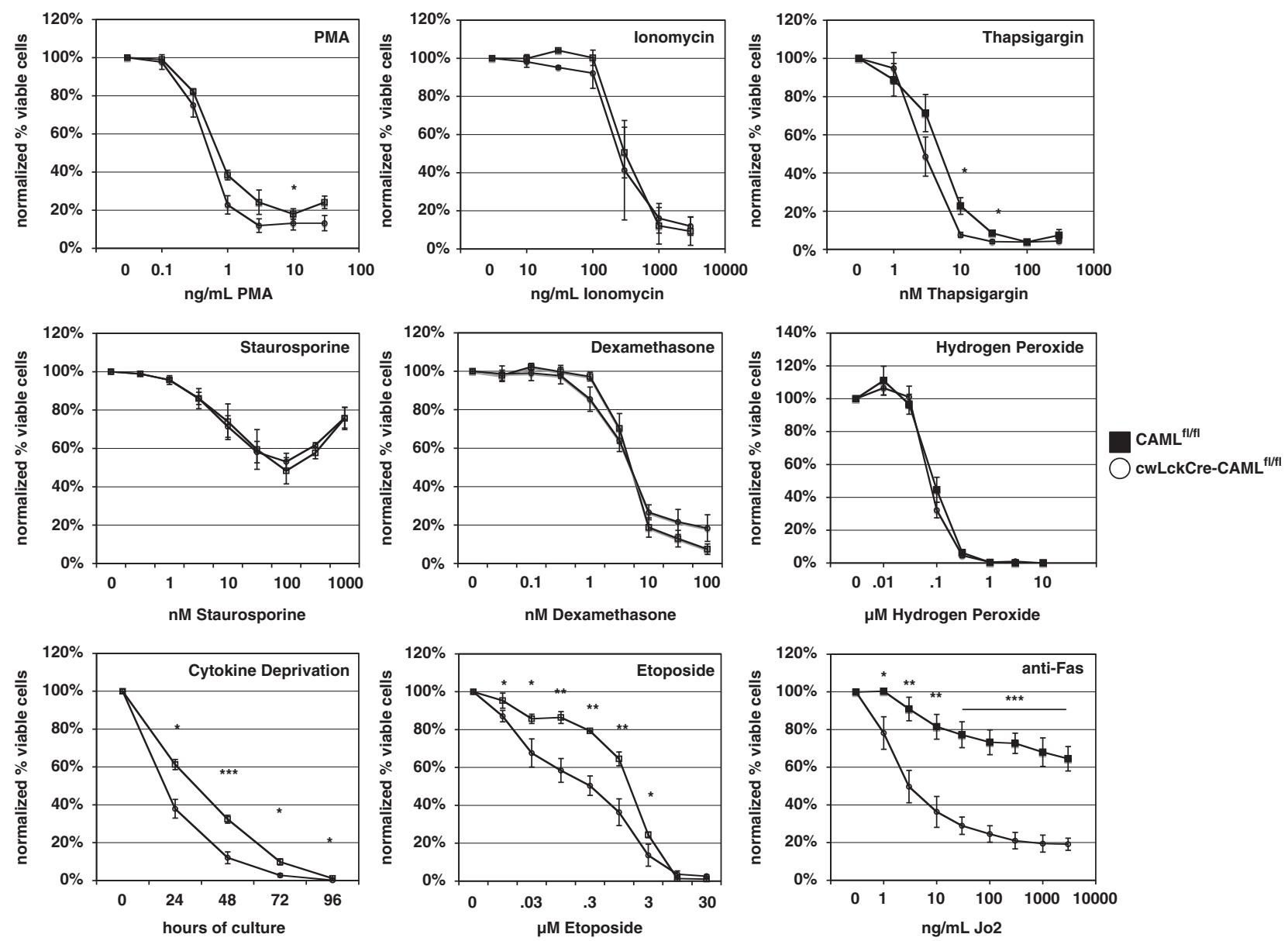

Figure 3 cwLckCre-CAML ${ }^{\text {fl/fl }} \mathrm{CD} 4+\mathrm{CD} 8+$ thymocytes show abnormally increased susceptibility to a subset of apoptotic stimuli. Total thymocytes $\left(1 \times 10^{6}\right)$ were cultured for $14 \mathrm{~h}$ with graded concentrations of the indicated reagents. Cells were stained with anti-CD4 plus anti-CD8 antibodies, Annexin V-Cy5, and propidium iodide to quantify cell survival. The average of three to five independent experiments is shown. Error bars represent standard error of the mean. Cytokine deprivation: thymocytes $\left(1 \times 10^{6}\right)$ were cultured for 4 days in regular medium in the absence of additional exogenous cytokines. Cell survival was examined daily as described above. One representative of three independent experiments is shown. Error bars represent standard error of the mean. ${ }^{\star} P<0.05,{ }^{\star \star} P<0.005$, ${ }^{\star \star \star} P<0.001$

Fas is not required for the enhanced apoptosis caused by CAML deficiency. As CAML-deficient thymocytes exhibited abnormally increased sensitivity to Fas-induced apoptosis, we explored whether Fas is critical for the abnormal thymocyte reduction caused by loss of CAML. Fas-mediated apoptosis was dependent on caspase activity, as treatment with ZVAD rescued both $\mathrm{cwLckCre-CAML}{ }^{\mathrm{fl} / \mathrm{fl}}$ and $\mathrm{CAML}^{\mathrm{fl} / \mathrm{fl}}$ cells from this death (Figure $4 \mathrm{a}$ and b). Next, we analyzed Fas surface expression on $\mathrm{cwLckCre-CAML} \mathrm{Ll}^{\mathrm{fl} / \mathrm{ll}}$ and $\mathrm{CAML}^{\mathrm{fl} / \mathrm{fl}}$ littermates and found that the levels were comparable (Figure 4c). The increased sensitivity to Fas stimulation was unexpected, as evidence suggests that Fas does not have a function in the developmentally programed death of thymocytes. ${ }^{22}$ Thus, we considered two possible scenarios: one in which the Fas receptor had been inappropriately activated in the absence of CAML, and another in which the Fas sensitivity of $\mathrm{cwLckCre}^{-C A M L} \mathrm{~L}^{\text {fl/fl }}$ cells reflected a deficiency of a central survival pathway within the cells. To distinguish between these two possibilities, cwLckCre$\mathrm{CAML}^{\mathrm{fl} / \mathrm{fl}}$ mice were crossed to Fas-deficient Fas ${ }^{\mathrm{Ipr} / \mathrm{pr}}$ mice. ${ }^{23}$ Interestingly, loss of Fas did not cause a rescue of thymic cellularity in cwLckCre-CAML ${ }^{\text {fl/fl. }} ; F^{\prime} s^{l p r / p r}$ mice (Figure $4 \mathrm{~d}$, compare third and fourth columns). This supports the notion that Fas does not mediate the abnormally enhanced in vivo death of $\mathrm{cwLckCre}^{-C A M L} \mathrm{~L}^{\mathrm{fl} / \mathrm{fl}}$ thymocytes, but instead suggests that these cells have a more general aberration in survival that renders them more sensitive to Fas stimulation in vitro plus other death stimuli.

Others have used cwLckCre mice for multiple analyses and have not reported non-specific toxicity because of thymic Cre expression. Nonetheless, to rule out a possible cytotoxic effect $^{24}$ of Cre in our mice, we also analyzed cwLckCre$\mathrm{CAML}^{+/+}$mice for overall thymic numbers and sensitivity to Fas-mediated apoptosis. As seen in Figure 4e-f, CAML loss, and not the cre transgene, was responsible for the loss of thymic cellularity and the abnormally increased sensitivity to Fas-mediated apoptosis.

Loss of Bim partially rescues thymocyte survival in CAML-deficient mice. The pro-apoptotic BH3-only protein Bim has been shown to be essential for the initiation of several pathways that induce apoptosis in thymocytes, ${ }^{7}$ 
a

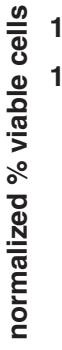

b

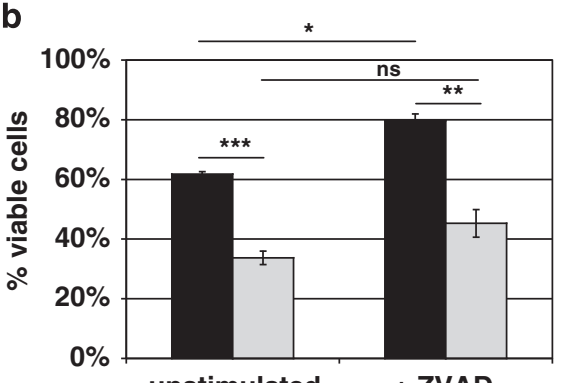

unstimulated

+ ZVAD

CAML $^{\mathrm{f} / \mathrm{fl}}$

cwLckCre-CAML $^{\mathrm{f} / \mathrm{fl}}$

-O-cwLckCre-CAML ${ }^{\text {fl/fl }}$

$-\square-$ CAML $^{\mathrm{fl} / \mathrm{fl}}+$ ZVAD

-- - - cwLckCre-CAML ${ }^{\text {fl/fl }}+$ ZVAD

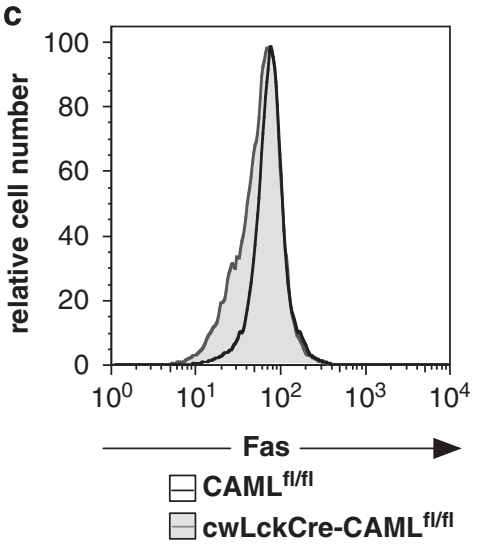

d

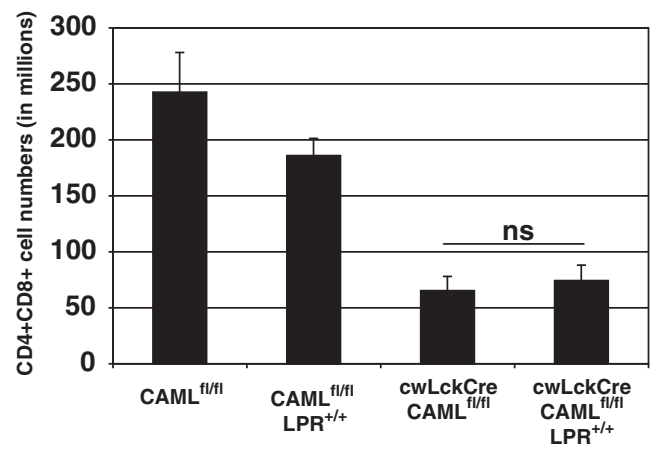

f

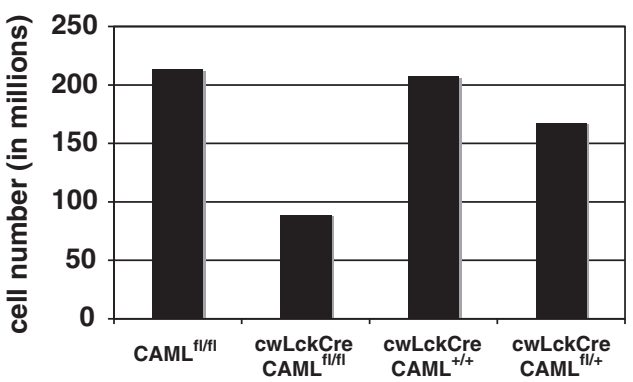

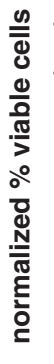

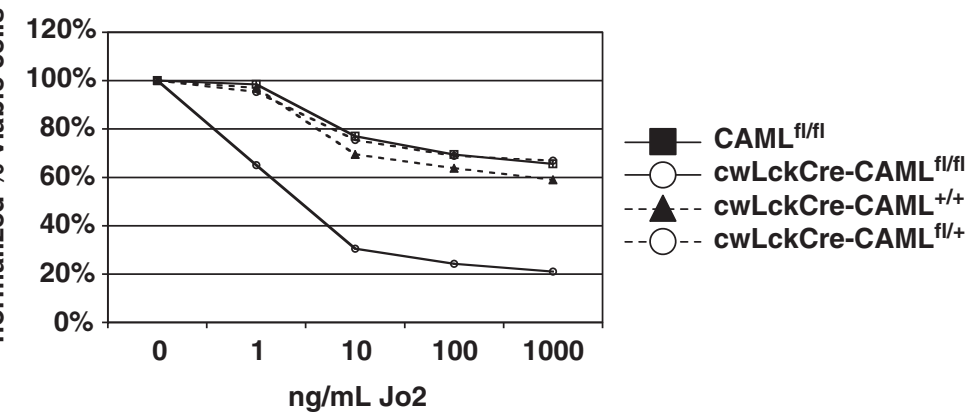

Figure 4 Fas is not essential for the abnormally increased apoptosis of cwLckCre-CAML ${ }^{\text {flftl }}$ thymocytes. (a) Caspase inhibition protects $\mathrm{CWLCKCre}^{\mathrm{f}} \mathrm{CAML} \mathrm{L}^{\mathrm{flfl}}$ thymocytes against Fas-induced apoptosis. Thymocytes $\left(1 \times 10^{6}\right)$ were cultured for $14 \mathrm{~h}$ with graded concentrations of anti-mouse Fas antibody with or without $50 \mu \mathrm{M}$ ZVAD. Cells were stained with anti-CD4 plus anti-CD8 antibodies, Annexin V-Cy5, and propidium iodide to quantify cell survival. The average of three independent experiments is shown. (b) Non-normalized viability of thymocytes after an overnight incubation with or without $50 \mu \mathrm{M}$ ZVAD. Cell survival was quantified as described above. One representative of three independent experiments is shown. (c) Thymocytes from $\mathrm{cwLCkCre}-\mathrm{CAML}^{\mathrm{fl} / \mathrm{fl}}$ mice express normal levels of Fas. Freshly isolated thymocytes from $\mathrm{cwL}_{\mathrm{LKCre}} \mathrm{CAML} \mathrm{L}^{\mathrm{fl} / \mathrm{fl}}$ mice or littermate controls were stained for surface expression of CD4, CD8, and Fas. The histogram shows Fas surface expression on CD4 + CD8 + cells. One

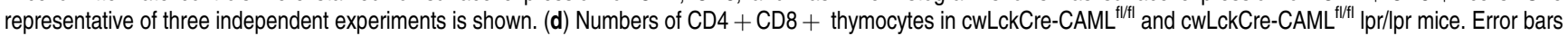
represent standard error of the mean. (e) Deletion of CAML, and not cre expression, is responsible for the decreased thymic cellularity and increased Fas susceptibility. Thymi from 3- to 6-week-old mice CAML ${ }^{\mathrm{flfl}}$ cwLckCre-CAML ${ }^{\mathrm{flfl}}$ cwLckCre-CAML ${ }^{+/+} \mathrm{cwLCkCre}^{-C A M L} \mathrm{~L}^{\mathrm{fl}+}$ were tweezed into single cell suspensions and counted. (f) Thymocytes $\left(1 \times 10^{6}\right)$ were cultured for $14 \mathrm{~h}$ with graded concentrations of anti-mouse Fas antibody (Jo2). Cells were stained with anti-CD4 plus anti-CD8 antibodies, Annexin V-Cy5, and propidium iodide to quantify cell survival. The average of two independent experiments is shown. ${ }^{\star} P<0.05,{ }^{* \star} P<0.005,{ }^{* \star \star} P<0.001$

including cytokine withdrawal and calcium flux. We, therefore, crossed $\mathrm{bim}^{-1-}$ mice with the conditional CAML knockout mice to test whether Bim is required for the reduction in cell numbers observed in cwLckCre-CAML ${ }^{\mathrm{fl} / \mathrm{fl}}$ thymi. Interestingly, cwLckCre-CAML ${ }^{\mathrm{fl} / \mathrm{fl}} ; \mathrm{bim}^{-1-}$ thymi showed a significant increase in the number of DP thymocytes. Although 
a
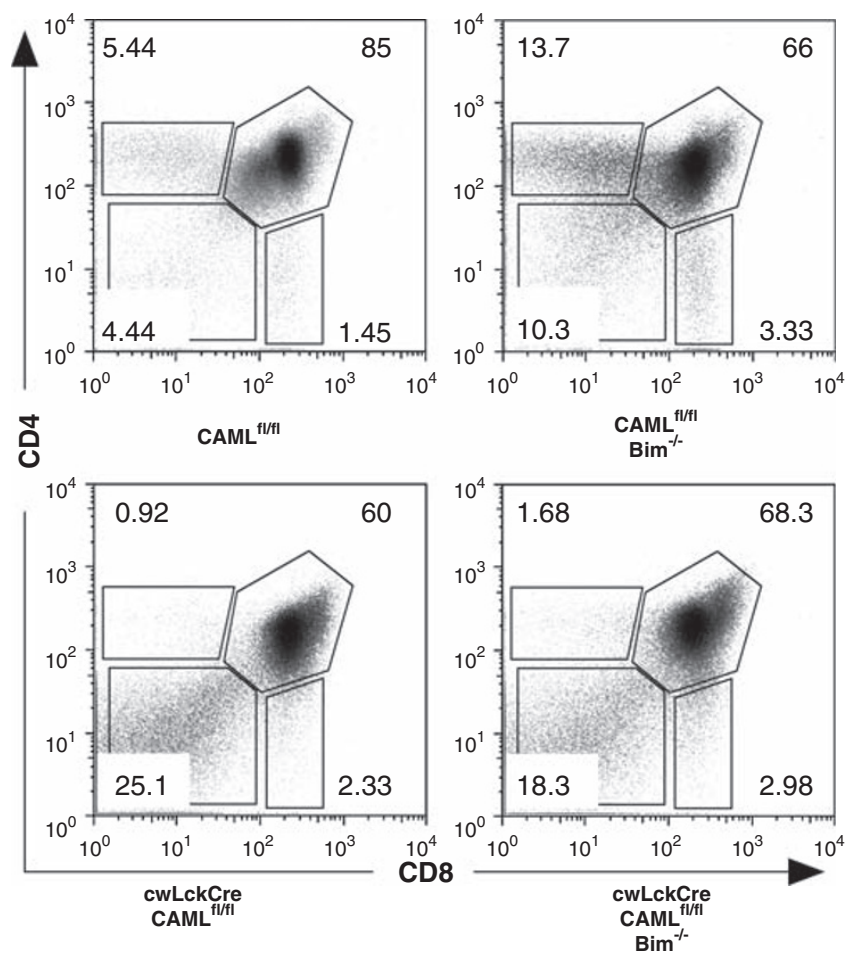

b

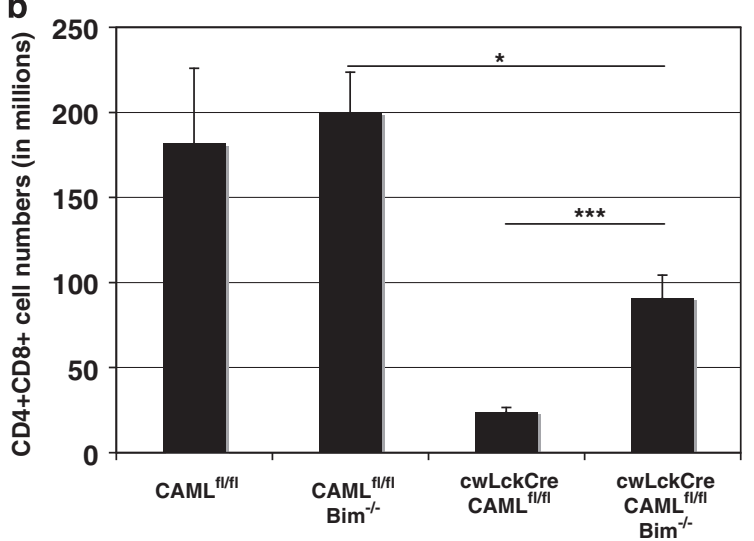

C

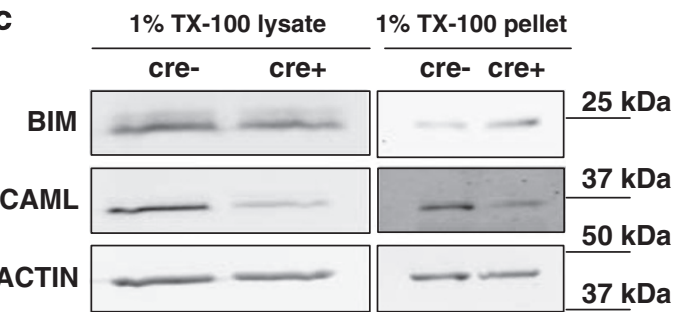

d cytosol mitochondrial

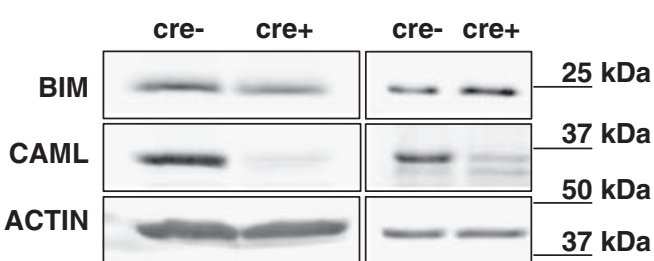

Figure 5 Bim deficiency significantly rescues intrathymic T-cell development in cwLckCre-CAML ${ }^{\mathrm{fl} / \mathrm{fl}}$. (a) CD4/CD8 thymic profiles of freshly isolated thymocytes, comparing

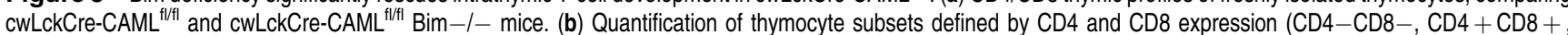

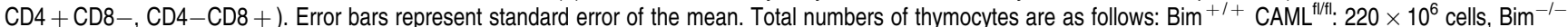

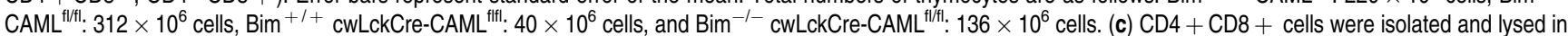
$1 \%$ TX-100 lysis buffer. Lysates were centrifuged at $17000 \times g$ for $10 \mathrm{~min}$ and pellets were suspended in Laemmli sample buffer. Western blots show Bim levels in the supernatant and pellet fractions. (d) Mitochondria were isolated from CD4 $+\mathrm{CD} 8+$ thymocytes and examined for levels of Bim. ${ }^{*} P<0.05,{ }^{* \star \star} P<0.001$

cwLckCre-CAML ${ }^{\text {fl/fl }}$ mice had only $13 \%$ of the numbers of DP cells compared with $\mathrm{CAML}^{\mathrm{fl} / \mathrm{fl}}$ animals, cwLckCre-CAML ${ }^{\mathrm{fl} / \mathrm{fl} \text {; }}$ $\mathrm{bim}^{-1-}$ mice had $46 \%$ of the numbers of these thymocytes compared with $\mathrm{CAML}^{\mathrm{fl} / \mathrm{fl}} ;$ bim $^{-/-}$littermate controls (Figure $5 \mathrm{a}$ and $b$ ), indicating that Bim must contribute to the enhanced death of CAML-deficient thymocytes.

Given that Bim appeared responsible for a significant portion of thymocyte death elicited by loss of CAML, we examined whether Bim expression is abnormal in CAMLdeficient cells. We first evaluated total cellular levels of Bim in CD4 + CD8 + DP cells and found it to be comparable or slightly diminished in the absence of CAML when compared with control cells (Figure $5 \mathrm{c}$ ). In addition to total cellular levels, $\mathrm{Bim}$ is also regulated by intracellular localization, ${ }^{13}$ including subcellular localization to the mitochondrial outer membrane, and by association with pro-survival Bcl-2 family members. ${ }^{25}$
We found that in CAML-deficient cells, Bim was reproducibly increased in the pellet fraction of cells lysed with 1\% Triton $\mathrm{X}-100$ (TX-100) and modestly increased in isolated mitochondria (Figure $5 \mathrm{~d}$ ), indicating that loss of CAML causes mislocalization of Bim.

T-cell receptor interaction with peptide/MHC complexes is not required for the enhanced apoptosis of CAMLdeficient thymocytes. Bim is essential for thymocyte apoptosis caused by strong TCR stimulation and critical for negative selection of autoreactive thymocytes. As we earlier reported that jmLckCre-CAML ${ }^{\text {fl/fl }} \mathrm{T}$ lymphocytes exhibit abnormally increased T-cell receptor stimulation, ${ }^{19}$ it appeared likely that augmented TCR signaling might be responsible for their abnormally increased apoptosis. Others have shown the function of TCR signaling in DP thymocyte 
killing in MINK-deficient mice by removing class I and II major histocompatibility antigens. ${ }^{26}$ In a similar manner, we examined whether $\mathrm{MHC} / \mathrm{T}$-cell receptor interaction was required for the enhanced death of cwLckCre-CAML $L^{f / f l}$ thymocytes by crossing cwLckCre-CAML ${ }^{\text {fl/fl }}$ mice with MHC class II-deficient $\left(\mathrm{Ab}^{0}\right)^{27}$ and $\mathrm{MHC}$ class I-deficient $\left(\beta 2-\right.$ microglobulin $\left.^{-l-}\right)$ mice. $^{28}$ In contrast to thymocytes lacking MINK in which MHC deficiency rescued normal DP development, loss of MHC did not rescue the survival of DP thymocytes in cwLckCre-CAML ${ }^{f / f l}$ mice (Figure $6 a$ and $\mathrm{b}$ ). This indicates that $\mathrm{T}$-cell receptor/MHC interactions are not required for the abnormally increased death of CAML-deficient pre-T cells.

\section{Abnormally elevated levels of reactive oxygen species in cwLckCre-CAML ${ }^{f / f l}$ mice. Reactive oxygen species (ROS) have been reported to induce Bim-dependent death in T cells. ${ }^{29}$ As loss of Bim increases thymocyte numbers in the absence of CAML, we compared ROS levels between}

CAML-deficient and control thymocytes by intracellular staining with DCFDA. cwLckCre-CAML fl/fl CD4+CD8+ thymocytes were reproducibly found to have elevated ROS levels (Figure $7 a$ and b) in comparison with cells from littermate control animals. ROS in cwLckCre-CAML ${ }^{f / f l}$ cells appeared to be of mitochondrial origin, as verified by staining with the mitochondrial-localizing ROS dye Mitosox ${ }^{30}$ (Figure 7c).

To ensure that DCFDA staining was indeed labeling ROS, we administered the antioxidant $\mathrm{N}$-acetyl-cysteine (NAC) to mice to reduce ROS, removed thymi, and then stained the cells with DCFDA. As expected, treatment of mice with NAC reduced the high ROS levels found in thymocytes from CAML-deficient mice (Figure 7d). In addition, we treated cells in vitro with inhibitors of ROS generation: diphenyleneiodonium chloride (DPI), an inhibitor of NADPH oxidase, and carbonyl cyanide-p-trifluoromethoxyphenylhydrazone (FCCP), a mild decoupling agent that reduces mitochondrial ROS when used at low concentrations. ${ }^{31}$ a

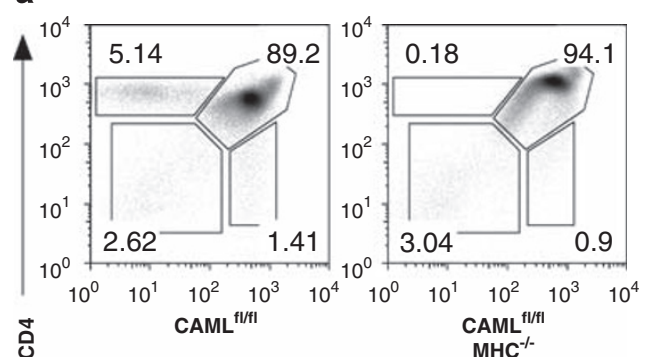

苍

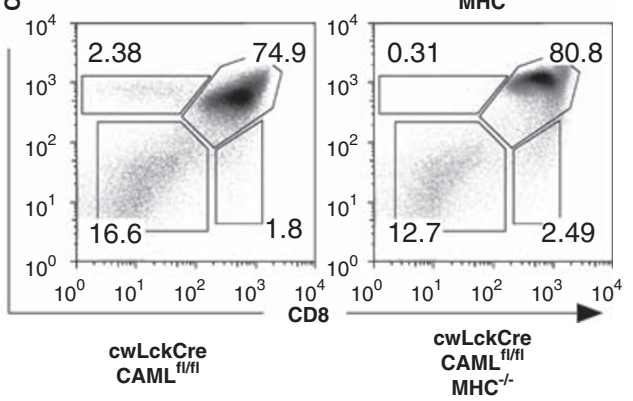

b

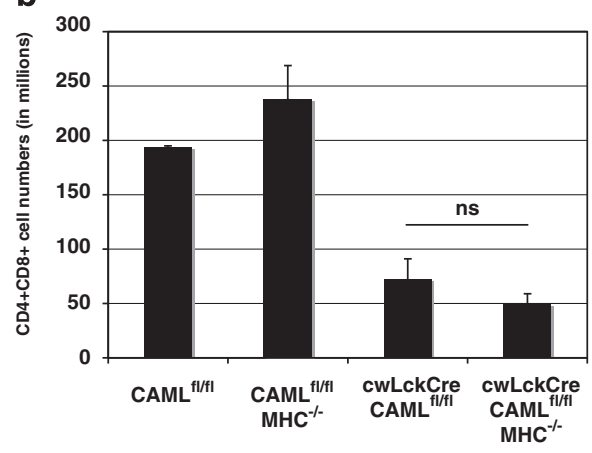

Figure 6 T-cell receptor ligand (MHC) deficiency does not rescue the defect in thymocyte development in cwLckCre-CAML fl/fil mice. (a) Representative flow cytometry profiles of anti-CD4 plus anti-CD8 antibody stained, freshly isolated thymocytes from CAML ${ }^{\mathrm{flfl}}$ mice with or without the cwLckCre transgene that contained or lacked $\beta 2$-microglobulin and class II major histocompatibility (MHC) proteins ( $\beta 2$-microglobulin-/- and class II MHC-/- mice are denoted MHC-). (b) Total numbers of $\mathrm{CD} 4+\mathrm{CD} 8+$ thymocytes. Error bars represent standard error of the mean

Figure 7 cwLckCre-CAML ${ }^{\text {fl/fl }}$ thymocytes contain abnormally increased levels of ROS. (a) Freshly isolated thymocytes from $\mathrm{cWLckCre}^{\mathrm{C}} \mathrm{CAML}^{\text {fl/fl }}$ mice and littermate controls were stained with anti-CD4 plus anti-CD8 antibodies and the ROS-specific dye 6 -carboxy-2', $7^{\prime}$-dichlorodihydrofluorescein diacetate, di(acetoxymethyl ester) (DCFDA). Histograms depicting ROS levels in each CD4/CD8 subset are shown. One representative of three independent experiments is shown. (b) Quantitation of the ROS staining in the CD4 + CD8 + thymic sub-population. The average of three independent experiments is shown. (c) Freshly isolated thymocytes from $\mathrm{CwLCkCre-CAML}^{\mathrm{fl} / \mathrm{fl}}$ mice and littermate controls were stained with anti-CD4 plus anti-CD8 antibodies and the mitochondrial ROS-specific dye, Mitosox. Levels of mitochondrial ROS found in CD4-CD8 - and CD4 + CD8 + thymic sub-populations are shown. One representative of three independent experiments is shown. (d) Mice of the indicated genotypes were fed NAC in their water at $10 \mathrm{mg} / \mathrm{ml}$ for 2 weeks. Thymocytes were removed and examined for levels of ROS through DCFDA staining. (e) Thymocytes were treated for $2 \mathrm{~h}$ with DPI plus FCCP and were then stained with DCFDA to determine percent inhibition of ROS levels. One representative experiment of two independent experiments is shown. (f) Anti-oxidant treatment reduces Fas-mediated apoptosis in cwLckCre-CAML ${ }^{\text {flff }}$ thymocytes. Thymocytes $\left(1 \times 10^{6}\right)$ from mice of the indicated genotypes were cultured for $14 \mathrm{~h}$ with anti-mouse Fas antibody with or without NAC, a potent antioxidant. Cells were stained with anti-CD4 plus anti-CD8 antibodies, Annexin V-Cy5, and propidium iodide to quantify cell survival. The average of three independent experiments is shown. Error bars represent standard error of the mean. DN, double-negative; DP, double-positive; $\mathrm{SP}$, single-positive thymocytes. (g) Anti-oxidant treatment reduces cytokine deprivation induced apoptosis of $\mathrm{cWLCkCre-CAML}^{\text {f/fl }}$ thymocytes. Experimental set-up and analysis were the same as for (f) except neither serum nor anti-Fas antibody was added. One representative experiment of two is shown 
We found that both reagents reduced ROS levels to a greater extent in the cwLckCre-CAML ${ }^{f / f l}$ cells than within $C A M L^{f l / f l}$ cells (Figure 7e).
Abnormally increased ROS levels could be a cause of death or simply a downstream consequence of programmed cell death. To distinguish between these possibilities, we

b
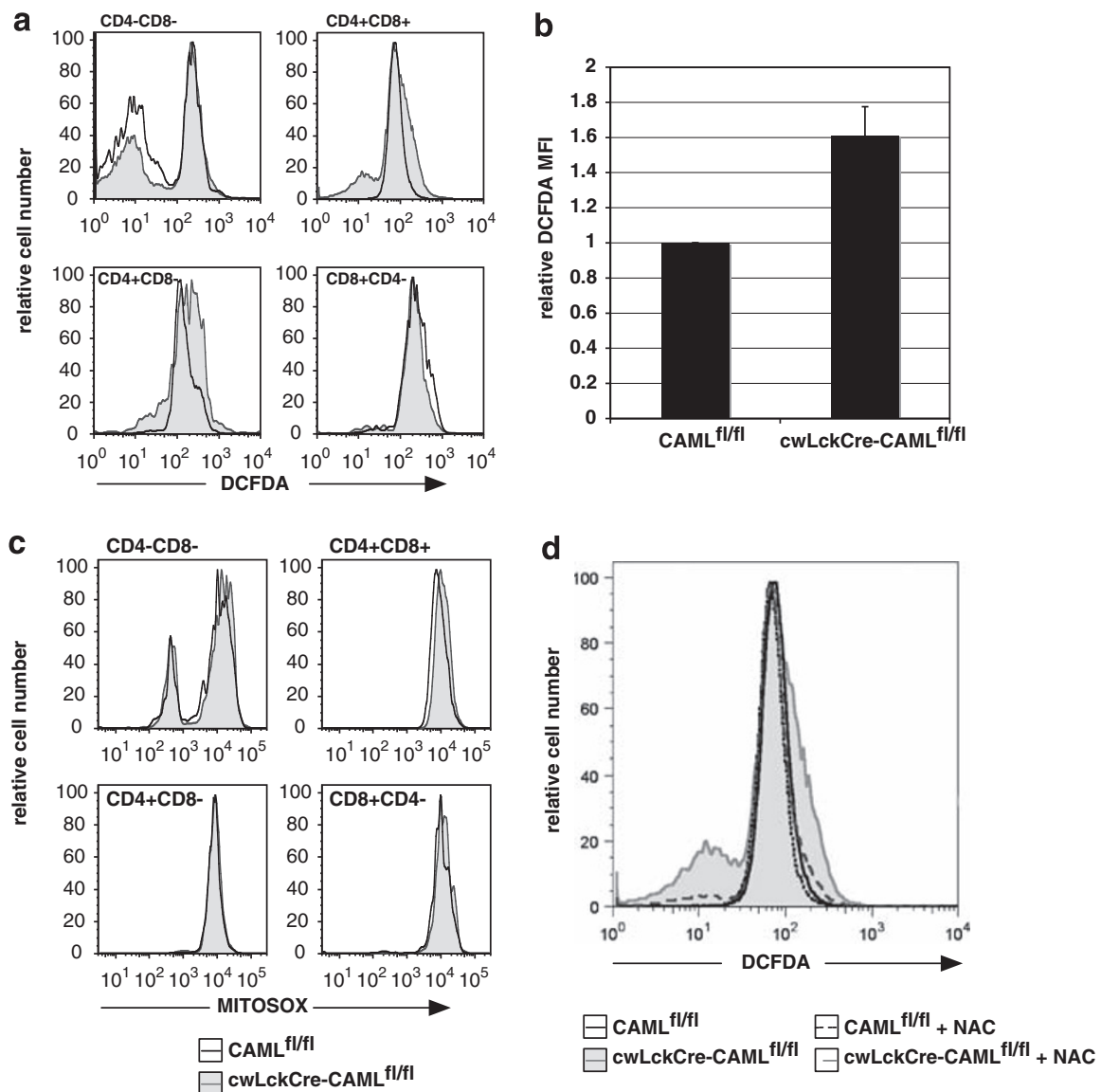
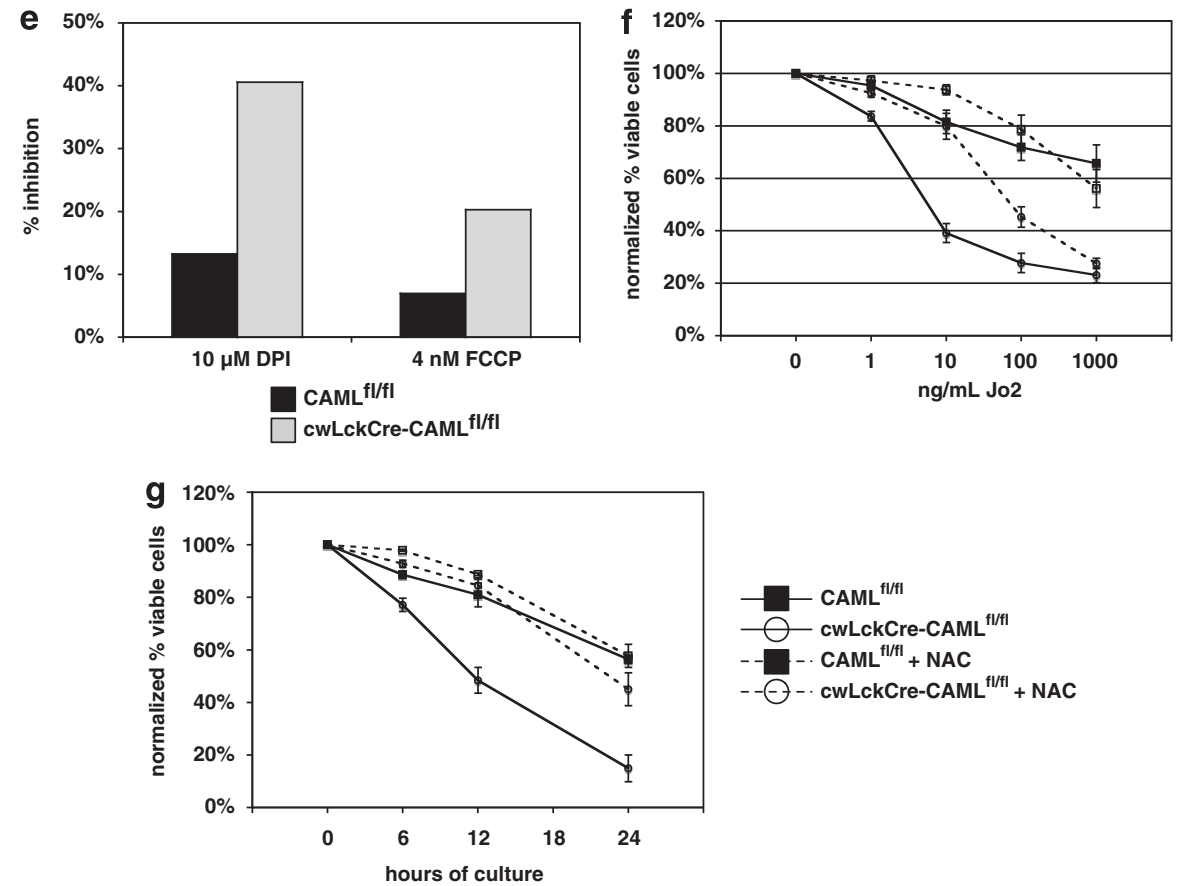
treated $c w L c k C r e-C A M L^{f / f l}$ and $C A M L^{f / f l}$ cells with NAC during stimulation of cells with anti-Fas antibody. Although addition of NAC had little effect on normal thymocytes, NACtreated cwLckCre-CAML ${ }^{\text {fl/fl }}$ cells were significantly protected from Fas-induced apoptosis (Figure 7f), indicating that ROS are required for the abnormally increased sensitivity of CAML-deficient thymocytes to Fas-mediated death. To determine whether NAC could also diminish the sensitivity of cwLckCre-CAML ${ }^{f / f l}$ cells to other apoptotic stimuli, we added NAC to cells immediately after isolation from the thymus and cultured them for 6,12 , and $24 \mathrm{~h}$ in simple medium (to mimic cytokine deprivation). Remarkably, NAC was able to augment the viability of cwLckCre-CAML ${ }^{f / f l}$ thymocytes cultured without cytokines at each time point (Figure7g).

\section{Discussion}

Here, we establish an essential function for CAML in maintaining the survival of developing thymocytes. CAML does not protect thymocytes indiscriminately against all cytotoxic insults; rather, it protects them from Fas stimulation, etoposide treatment, and cytokine deprivation, but not from treatment with phorbol ester, ionomycin, thapsigargin, staurosporine, dexamethasone, or hydrogen peroxide. Our data suggest that CAML does not prevent TCR or p53mediated death, but instead protects cells from Bim-induced death, most likely by blocking the production of ROS. Although earlier studies suggested a connection between CAML and cell survival, the function of CAML in this process has been a mystery. CAML interacts with $K 7,{ }^{32}$ a viral protein important for maintaining cell viability during infection, and E3-6.7K, a TACI viral homolog ${ }^{33}$ that was shown to increase survival of cells exposed to extrinsic apoptotic stimuli. ${ }^{34}$

What is the molecular mechanism by which CAML potentiates thymocyte survival? Several important steps of this process are revealed by this work. First, CAML-deficient cells have enhanced levels of ROS. ROS have been implicated in many types of cell death, including activationinduced apoptosis of T cells ${ }^{35}$ and increasing the susceptibility of cells to extrinsic death stimuli. ${ }^{36}$ The decreased redox potential of CAML-deficient cells may render them more susceptible to Fas ligation and cytokine deprivation, as evidenced by the ability of the antioxidant NAC to reduce the susceptibility of CAML-deficient cells to Fas stimulation and cytokine deprivation. The ability of NAC to inhibit this enhanced death also provides evidence that the high ROS levels are not a consequence of cellular demolition, but rather that the ROS generated in CAML-deficient cells contribute to increased apoptosis signaling.

Second, the death of thymocytes lacking CAML requires the pro-apoptotic $\mathrm{BH} 3-$ only Bcl-2 family member Bim. Bim has been shown to be critical for negative selection of autoreactive thymocytes and immature B cells, and for cytokine-withdrawal-induced death of a broad range of cell types, ${ }^{6}$ and Bim is induced by TCR or BCR signaling ${ }^{7,37}$ and ROS. $^{38}$ In contrast to our earlier study of more mature single-positive thymocytes that showed abnormally augmented TCR signaling as a consequence of CAML deficiency, ${ }^{19}$ we did not find evidence for TCR signal dependence of the enhanced death of CAML-deficient thymocytes, although Bim is clearly required for the excess thymocyte death. $\mathrm{Ca}^{2+}$ signaling also regulates $\mathrm{Bim}^{39}$ but we do not suspect that CAMLdeficient cells have abnormal $\mathrm{Ca}^{2+}$ influx, because there was no defect in pro-T-cell proliferation, which also requires $\mathrm{Ca}^{2+}$ signaling. Moreover, CAML-deficient thymocytes had a normal content of intracellular-free $\mathrm{Ca}^{2+}$ (data not shown). We examined how Bim might be activated to promote the destruction of CAML-deficient cells and found that Bim was neither increased at the protein level, nor did it show altered migration on SDS-PAGE, which would suggest a difference in phosphorylation. However, in the absence of CAML, Bim was localized more strongly to the pellet fraction of cells lysed with $1 \%$ Triton lysis buffer. Although we have not conclusively shown that CAML directly alters Bim localization, in light of CAML's function in trafficking the EGFR, ${ }^{16}$ it is tempting to speculate that CAML may have a function in preventing Bim from moving to the mitochondria.

Precisely, how CAML acts to block ROS induction and Bim activation is not yet clear. However, CAML has earlier been shown to interact with several protein kinases, including EGFR, ${ }^{16}$ Lck, $^{19}$ and Hck (unpublished data). Modulation of the activity or intracellular location of one or more such kinases may, therefore, constitute one of the critical functions of CAML. Indeed, in preliminary studies, we have identified a physical interaction between the serine-threonine kinase Raf-1 and CAML (Supplementary Figure S2). Notably, Raf has been implicated in signaling pathways that inhibit apoptosis, ${ }^{40}$ and dominant-negative mutants of Raf block thymocyte development. ${ }^{41}$ Moreover, Raf- 1 was shown to regulate cellular levels of ROS and is thought to thereby control cellular responses to cytokine withdrawal. ${ }^{31}$ Importantly, for this study, it has been shown that pharmacological blockade of Raf signaling kills certain tumor cells through Bim induction. ${ }^{42}$ Raf- 1 has also been reported to protect cells from external apoptotic stimuli, including Fas ligation, ${ }^{43}$ a stimulus to which CAML-deficient thymocytes are extremely sensitive. It is, therefore, tempting to speculate that CAML might regulate the survival function of Raf-1. Future studies will be required to determine whether the Raf-CAML interaction participates in the pro-survival function of CAML in this cell type.

\section{Materials and Methods}

Mice. All experiments used 3-6-week-old gender-matched littermate controls that were on a mixed C57BL/6x129/SvJ background. Dr. David Tran developed CAML ${ }^{\mathrm{flfl}}$ mice, ${ }^{19}$ which were generated using 129/SvJ ES cells. cwlckcre (C57BL/6NTacTgN(Lck-Cre) stock number: 004197) mice were purchased from Taconic (Hudson, NY, USA). Bim-deficient (B6.129S1-Bcl2111 $1^{\mathrm{tm} 1.1 \mathrm{Ast} / \mathrm{J}}$ stock number: 004525) and LPR (B6.MRL-Fas ${ }^{\mathrm{IPr}} / \mathrm{J}$ stock number: 000482) mice (both backcrossed onto a C57BL/ 6 background for $>20$ generations) were purchased from Jackson Labs (Bar Harbor, ME, USA). p53-deficient mice were a gift from Dr. Jan VanDeurson. MHC-deficient ( $\beta 2$-microglobulin-/- and class II MHC-/-) mice were a gift from Dr. Chella David. All animal experiments were performed according to IACUC guidelines and were approved by the IACUC.

Reagents. Ionomycin (407952) and thapsigargin (586005) were purchased from Calbiochem (Gibbstown, NJ, USA). PMA (13139-019) was purchased from Gibco (Carlsbad, CA, USA). Etoposide (E1383), hydrogen peroxide (349887), DPI(D2926), carbonyl cyanide-p-trifluoromethoxyphenyl-hydrazone (FCCP C2920), and NAC (A9165) were purchased from Sigma (St. Louis, MO, USA). Jo2 (554254) hamster anti-mouse Fas antibody was purchased from BD Pharmingen (Franklin Lakes, NJ, USA). 
Flow cytometry. Labeled anti-CD4 (clone RM4-5), anti-CD8 (clone 53-6.7), anti-c-kit (clone 2B8), and anti-CD25 (clone 3C7) antibodies, propidium iodide (\#51-66211E), and Cy5-conjugated Annexin V (\#559934) were obtained from BD Pharmingen. Cocktails of lineage marker-specific antibodies were a generous gift from Dr. Virginia Shapiro and consisted of FITC-labeled antibodies specific for Mac-1 (CD11b), GR-1 (Ly6G/C), CD8 $\alpha, \mathrm{TCR} \beta, \mathrm{TCR} \gamma \delta, \mathrm{CD} 3 \varepsilon, \mathrm{B} 220, \mathrm{CD} 19$ Ter119, and NK1.1. DCFDA (C2938) was purchased from Invitrogen (Carlsbad, CA, USA). Mitosox (M36008) was purchased from Molecular Probes (Carlsbad, CA USA). Analyses were performed on BD FACS Calibur (Franklin Lakes, NJ, USA) and Accuri $\mathrm{C} 6$ flow cytometers.

Cell survival assays. Thymi were removed from mice and tweezed into a single cell suspension. Two million thymocytes were cultured for $16 \mathrm{~h}$ in 24 -well plates with the indicated reagents. Cells were then stained with anti-CD4 and antiCD8 antibodies, Annexin V-Cy5, and PI to assess DP thymocyte viability.

Immunoprecipitation and western blotting. CD4 + CD8 + DP cells were isolated using Miltenyi MACS multisort kit. Cells were lysed for $5 \mathrm{~min}$ with TX-100 lysis buffer on ice (1\% TX-100, $20 \mathrm{mM}$ HEPES [pH 7.4], $5 \mathrm{mM} \mathrm{NaCl}, 5 \mathrm{mM}$ $\mathrm{MgCl} 2,1 \mathrm{mM}$ EGTA, $1 \mathrm{mM}$ EDTA, $1 \mathrm{mM}$ lodoacetamide, $100 \mu \mathrm{M}$ Na2VO4, $1 \mathrm{mM}$ PMSF, $10 \mu \mathrm{g} / \mathrm{ml}$ leupeptin, and $45 \mu \mathrm{g} / \mathrm{ml}$ aprotinin). Proteins were precipitated with $5 \mu \mathrm{g}$ of antigen-specific antibodies: CAML (polyclonal rabbit serum raised against amino-acids 1-189 of CAML) and Raf-1 (BD Pharmingen 610152) or isotypematched control antibodies (BD Pharmingen). Western blots were probed for CAML (polyclonal rabbit serum raised against amino-acids 1-189 of CAML), Raf-1 (BD Pharmingen 610152), actin (Millipore, Billerica, MA, USA; C4), and Bim (Cell Signaling, Billerica, MA, USA; 2819).

Mitochondrial isolation. CD8 + thymocytes (96-98\% pure for CD4 + CD8 + DP cells) were isolated using Miltenyi MACS CD8 isolation beads. Mitochondria isolation protocol was followed according to a protocol modified from Thompson and Winoto. ${ }^{44} \mathrm{~A}$ total of $60 \times 10^{6}$ cells were lysed in $10 \mathrm{mM} \mathrm{Hepes}-\mathrm{KOH}$, $\mathrm{pH} 7.9,10 \mathrm{mM} \mathrm{KCl}, 1.5 \mathrm{mM} \mathrm{MgCl}_{2}, 0.2 \mathrm{mM} \mathrm{PMSF}, 1 \mathrm{mM} \mathrm{DTT}$, and $0.6 \% \mathrm{NP}-40$. After $45 \mathrm{~min}$ on ice, lysates were centrifuged $300 \times g$ for $1 \mathrm{~min}$ to remove the nuclear fraction. Supernatant was transferred to a new tube and centrifuged at $700 \times g$ for $10 \mathrm{~min}$ and subsequently $17000 \times g$ for $40 \mathrm{~min}$. A brown mitochondrial pellet was observed after this final centrifugation. The supernatant, a cytosolic fraction, was removed and the mitochondrial pellet was lysed in $10 \mu$ l of the lysis buffer described above. Lysates were loaded onto a 15\% SDS-PAGE gel, transferred, and probed with Bim-specific (Cell Signaling 2819) and actin-specific (Millipore C4) antibodies.

\section{Conflict of interest}

The authors declare no conflict of interest.

Acknowledgements. Reagents and mice were kindly provided by Drs Chella David, Virginia Shapiro, and Jan VanDeurson. This work was supported by the National Institute of Heath (grant 2R01Al074320) (RJB), the Mayo Foundation (RJB), Joseph Bloom Children's Disease Research (RJB), NIH training grant T32 Al07425-14 (CE), and the Australian NHMRC (program 461221, fellowship 461229).

1. Starr TK, Jameson SC, Hogquist KA. Positive and negative selection of T cells. Annu Rev Immunol 2003; 21: 139-176.

2. Marsden VS, Strasser A. Control of apoptosis in the immune system: Bcl-2, BH3-only proteins and more. Annu Rev Immunol 2003; 21: 71-105.

3. Hsu SY, Lin P, Hsueh AJ. BOD (Bcl-2-related ovarian death gene) is an ovarian $\mathrm{BH} 3$ domain-containing proapoptotic $\mathrm{Bcl}-2$ protein capable of dimerization with diverse antiapoptotic Bcl-2 members. Mol Endocrinol 1998; 12: 1432-1440.

4. O'Connor L, Strasser A, O'Reilly LA, Hausmann G, Adams JM, Cory S et al. Bim: a novel member of the Bcl-2 family that promotes apoptosis. EMBO J 1998; 17: 384-395.

5. O'Reilly LA, Cullen L, Visvader J, Lindeman GJ, Print C, Bath ML et al. The proapoptotic $\mathrm{BH} 3$-only protein bim is expressed in hematopoietic, epithelial, neuronal, and germ cells. Am J Pathol 2000; 157: 449-461.

6. Bouillet $\mathrm{P}$, Metcalf D, Huang DC, Tarlinton DM, Kay TW, Kontgen F et al. Proapoptotic $\mathrm{Bcl}-2$ relative Bim required for certain apoptotic responses, leukocyte homeostasis, and to preclude autoimmunity. Science 1999; 286: 1735-1738.
7. Bouillet P, Purton JF, Godfrey DI, Zhang LC, Coultas L, Puthalakath $\mathrm{H}$ et al. BH3-only Bcl-2 family member Bim is required for apoptosis of autoreactive thymocytes. Nature 2002; 415 : 922-926

8. Hughes PD, Belz GT, Fortner KA, Budd RC, Strasser A, Bouillet P. Apoptosis regulators Fas and Bim cooperate in shutdown of chronic immune responses and prevention of autoimmunity. Immunity 2008; 28: 197-205.

9. Weant AE, Michalek RD, Khan IU, Holbrook BC, Willingham MC, Grayson JM. Apoptosis regulators Bim and Fas function concurrently to control autoimmunity and CD8+ T cell contraction. Immunity 2008; 28: 218-230.

10. Hutcheson J, Scatizzi JC, Siddiqui AM, Haines 3rd GK, Wu T, Li QZ et al. Combined deficiency of proapoptotic regulators Bim and Fas results in the early onset of systemic autoimmunity. Immunity 2008; 28: 206-217.

11. Shinjyo T, Kuribara R, Inukai T, Hosoi H, Kinoshita T, Miyajima $A$ et al. Downregulation of Bim, a proapoptotic relative of $\mathrm{Bcl}-2$, is a pivotal step in cytokine-initiated survival signaling in murine hematopoietic progenitors. Mol Cell Biol 2001; 21: 854-864.

12. Luciano F, Jacquel $A$, Colosetti $P$, Herrant M, Cagnol S, Pages $G$ et al. Phosphorylation of Bim-EL by Erk1/2 on serine 69 promotes its degradation via the proteasome pathway and regulates its proapoptotic function. Oncogene 2003; 22: 6785-6793.

13. Puthalakath $\mathrm{H}$, Huang DC, O'Reilly LA, King SM, Strasser A. The proapoptotic activity of the Bcl-2 family member Bim is regulated by interaction with the dynein motor complex. Mol Cell 1999; 3: 287-296.

14. Bram RJ, Crabtree GR. Calcium signalling in T cells stimulated by a cyclophilin B-binding protein. Nature 1994; 371: 355-358.

15. Holloway MP, Bram RJ. Co-localization of calcium-modulating cyclophilin ligand with intracellular calcium pools. J Biol Chem 1998; 273: 16346-16350.

16. Tran DD, Russell HR, Sutor SL, van Deursen J, Bram RJ. CAML is required for efficient EGF receptor recycling. Dev Cell 2003; 5: 245-256.

17. Liu $Y$, Malureanu L, Jeganathan KB, Tran DD, Lindquist LD, van Deursen JM et al. CAML loss causes anaphase failure and chromosome missegregation. Cell Cycle 2009; 8 : 940-949.

18. Orban PC, Chui D, Marth JD. Tissue- and site-specific DNA recombination in transgenic mice. Proc Natl Acad Sci USA 1992; 89: 6861-6865.

19. Tran DD, Edgar CE, Heckman KL, Sutor SL, Huntoon CJ, van Deursen J et al. CAML is a p56Lck-interacting protein that is required for thymocyte development. Immunity 2005; 23: 139-152.

20. Lee PP, Fitzpatrick DR, Beard C, Jessup HK, Lehar S, Makar KW et al. A critical role for Dnmt1 and DNA methylation in T cell development, function, and survival. Immunity 2001; 15: 763-774.

21. Villunger A, Michalak EM, Coultas L, Mullauer F, Bock G, Ausserlechner MJ et al. p53- and drug-induced apoptotic responses mediated by $\mathrm{BH} 3-$ only proteins puma and noxa. Science 2003; 302: 1036-1038.

22. Sidman $\mathrm{CL}$, Marshall JD, Von Boehmer H. Transgenic T cell receptor interactions in the lymphoproliferative and autoimmune syndromes of Ipr and gld mutant mice. Eur J Immunol 1992; 22: 499-504.

23. Watanabe-Fukunaga R, Brannan Cl, Copeland NG, Jenkins NA, Nagata S. Lymphoproliferation disorder in mice explained by defects in Fas antigen that mediates apoptosis. Nature 1992; 356: 314-317.

24. Schmidt-Supprian M, Rajewsky K. Vagaries of conditional gene targeting. Nat Immunol 2007; 8: 665-668.

25. Zhu Y, Swanson BJ, Wang M, Hildeman DA, Schaefer BC, Liu X et al. Constitutive association of the proapoptotic protein Bim with Bcl-2-related proteins on mitochondria in T cells. Proc Natl Acad Sci USA 2004; 101: 7681-7686.

26. McCarty N, Paust S, Ikizawa K, Dan I, Li X, Cantor H. Signaling by the kinase MINK is essential in the negative selection of autoreactive thymocytes. Nat Immunol 2005; 6 : 65-72.

27. Cosgrove D, Gray D, Dierich A, Kaufman J, Lemeur M, Benoist C et al. Mice lacking MHC class II molecules. Cell 1991; 66: 1051-1066.

28. Koller BH, Marrack $\mathrm{P}$, Kappler JW, Smithies O. Normal development of mice deficient in beta 2M, MHC class I proteins, and CD8+ T cells. Science 1990; 248: 1227-1230.

29. Sade H, Sarin A. Reactive oxygen species regulate quiescent T-cell apoptosis via the BH3-only proapoptotic protein BIM. Cell Death Differ 2004; 11: 416-423.

30. Mukhopadhyay P, Rajesh M, Hasko G, Hawkins BJ, Madesh M, Pacher P. Simultaneous detection of apoptosis and mitochondrial superoxide production in live cells by flow cytometry and confocal microscopy. Nat Protoc 2007; 2: 2295-2301.

31. Kuznetsov AV, Smigelskaite J, Doblander C, Janakiraman M, Hermann M, Wurm M et al. Survival signaling by $\mathrm{C}$-RAF: mitochondrial reactive oxygen species and $\mathrm{Ca} 2+$ are critical targets. Mol Cell Biol 2008; 28: 2304-2313.

32. Feng $P$, Park J, Lee BS, Lee SH, Bram RJ, Jung JU. Kaposi's sarcoma-associated herpesvirus mitochondrial $\mathrm{K} 7$ protein targets a cellular calcium-modulating cyclophilin ligand to modulate intracellular calcium concentration and inhibit apoptosis. J Virol 2002; 76: 11491-11504.

33. Grant JR, Moise AR, Jefferies WA. Identification of a novel immunosubversion mechanism mediated by a virologue of the B-lymphocyte receptor TACl. Clin Vaccine Immunol 2007; 14: 907-917.

34. Benedict CA, Norris PS, Prigozy TI, Bodmer JL, Mahr JA, Garnett CT et al. Three adenovirus E3 proteins cooperate to evade apoptosis by tumor necrosis factor-related apoptosis-inducing ligand receptor-1 and -2. J Biol Chem 2001; 276: 3270-3278. 
35. Hildeman DA, Mitchell T, Teague TK, Henson P, Day BJ, Kappler J et al. Reactive oxygen species regulate activation-induced T cell apoptosis. Immunity 1999; 10: 735-744.

36. Kamata H, Honda S, Maeda S, Chang L, Hirata H, Karin M. Reactive oxygen species promote TNFalpha-induced death and sustained JNK activation by inhibiting MAP kinase phosphatases. Cell 2005; 120: 649-661.

37. Enders A, Bouillet $P$, Puthalakath $H, X u Y$, Tarlinton DM, Strasser A. Loss of the proapoptotic $\mathrm{BH} 3-$ only $\mathrm{Bcl}-2$ family member Bim inhibits BCR stimulation-induced apoptosis and deletion of autoreactive B cells. J Exp Med 2003; 198: 1119-1126.

38. Ramjaun AR, Tomlinson S, Eddaoudi A, Downward J. Upregulation of two BH3-only proteins, Bmf and Bim, during TGF beta-induced apoptosis. Oncogene 2007; 26: 970-981.

39. Cante-Barrett K, Gallo EM, Winslow MM, Crabtree GR. Thymocyte negative selection is mediated by protein kinase $\mathrm{C}$ - and $\mathrm{Ca} 2+$-dependent transcriptional induction of bim [corrected]. J Immunol 2006; 176: 2299-2306.
40. Troppmair J, Rapp UR. Raf and the road to cell survival: a tale of bad spells, ring bearers and detours. Biochem Pharmacol 2003; 66: 1341-1345

41. O'Shea CC, Crompton T, Rosewell IR, Hayday AC, Owen MJ. Raf regulates positive selection. Eur J Immunol 1996; 26: 2350-2355.

42. Cragg MS, Jansen ES, Cook M, Harris C, Strasser A, Scott CL. Treatment of B-RAF mutant human tumor cells with a MEK inhibitor requires Bim and is enhanced by a $\mathrm{BH} 3$ mimetic. J Clin Invest 2008; 118: 3651-3659.

43. Piazzolla D, Meissl K, Kucerova L, Rubiolo C, Baccarini M. Raf-1 sets the threshold of Fas sensitivity by modulating Rok-alpha signaling. J Cell Biol 2005; 171 1013-1022.

44. Thompson J, Winoto A. During negative selection, Nur77 family proteins translocate to mitochondria where they associate with $\mathrm{Bcl}-2$ and expose its proapoptotic $\mathrm{BH} 3$ domain. J Exp Med 2008; 205: 1029-1036

\section{Supplementary Information accompanies the paper on Cell Death and Differentiation website (http://www.nature.com/cdd)}

